\title{
WELFARE IMPLICATIONS OF WASHINGTON WHEAT BREEDING PROGRAMS
}

\author{
LIA NOGUEIRA* \\ Assistant Professor, Department of Agricultural Economics, University of Nebraska-Lincoln \\ JOEL MICHALSKI \\ Postdoctoral Fellow, Agricultural and Resource Economics, International Maize and Wheat Improvement Center \\ (CIMMYT)
}

THOMAS L. MARSH AND VICKI MCCRACKEN

Professors, School of Economic Sciences, Washington State University

\begin{abstract}
We calculate the welfare effects of the Washington State University (WSU) wheat breeding programs for producers and consumers in Washington, Oregon, Idaho, and the United States, and for importers of U.S. wheat. We develop a partial equilibrium multiregion, multiproduct, multivariety trade model for wheat that provides consumer, producer, and total surplus for each wheat class and region. Our results provide evidence suggesting that WSU wheat breeding programs have increased welfare for the state of Washington, the United States, and importers of U.S. wheat.
\end{abstract}

Keywords. economic surplus, partial equilibrium, welfare, wheat breeding programs

JEL Classifications. F14, F17, Q11, Q16, Q18

\section{Introduction}

Wheat is an important commodity for the United States and the state of Washington, both at the domestic and international levels. Land Grant Universities, such as Washington State University (WSU), invest in research to improve wheat characteristics that will benefit both producers and consumers. Funds available for agricultural research, however, are a scarce resource that needs to be justified. Measuring the welfare effects of the WSU wheat breeding programs represents an important part of understanding the value of these programs.

We appreciate the comments and suggestions of the faculty and students who participated in the SES Graduate Research Seminar-Spring 2008 where a previous version of this work was presented. We also thank Cory Walters for helpful comments on an earlier draft. Research assistance was provided by Heather Johnson, Sasi Ponnaluru, and Justin Taylor. Partial funding for this project was provided by the Washington State University IMPACT Center and College of Agricultural, Human, and Natural Resources Sciences. Helpful comments and suggestions were provided by two anonymous reviewers.

*E-mail: lia.nogueira@unl.edu 
The main objective of this study is to calculate the welfare effects of the WSU wheat breeding programs for producers and consumers (wheat buyers) in Washington, Oregon, Idaho, and the United States, and for importers of U.S. wheat. This study will make several contributions to the literature. We extend previous work to develop a detailed multiregion, multiproduct, and multivariety model that includes spillover effects and accounts for the limited substitution among wheat classes. We use the approach by Michalski (2012) to estimate the yield improvement by wheat class because of the WSU breeding programs. Our framework and results will be useful to decision makers in the government because we evaluate expenditures on the WSU wheat breeding programs by calculating the welfare effects of these programs and comparing them with the associated costs. Based on the welfare results, we calculate a net present value (NPV) of $\$ 9.13$ million, a benefit-cost ratio (BCR) of 1.75 , and an internal rate of return (IRR) of $17.75 \%$ for the WSU breeding programs.

There are numerous studies analyzing the welfare economics of agricultural research. Most of these studies are based on the methodology initiated by Schultz (1953) and Griliches (1958) and further developed by Ayer and Schuh (1972) and Akino and Hayami (1975). Studies related to the impact of wheat breeding research started as early as the 1970s. Models have evolved and become more sophisticated and accurate with time. Most approaches focus on economic surplus measures, based on partial equilibrium or econometric models. These studies also differ in the representation of varietal improvement, with yield increase being the most popular. ${ }^{1}$ Some work has been done regarding the use of new technologies, specifically the potential benefits of genetically modified wheat research (Berwald, Carter, and Gruère, 2005; Crespi et al., 2005). None of these studies, however, incorporate multiple regions, wheat classes, and wheat varieties jointly in their analysis.

In particular, most studies focus on the benefits for the specific area of study (e.g., Blakeslee et al., 1973; Blakeslee and Sargent, 1982; Brennan, 1984, 1989; Byerlee and Traxler, 1995; Heisey, Lantican, and Dubin, 2002). Some studies incorporate different regions in their analysis (e.g., Barkley, 1997; Edwards and Freebairn, 1984; Nalley et al., 2008). Only a few studies, however, incorporate more than one dimension. Brennan, Godyn, and Johnston (1989) incorporate not only several regions but also quality aspects into an analysis based on a partial equilibrium framework for evaluating new wheat varieties. The authors estimate the change in producer and consumer surplus in Australia and the rest of the world (ROW) resulting from a research-induced shift in the supply curve. Zentner and Peterson (1984) incorporate different wheat classes for Canada. The authors perform an econometric analysis of whether public investment in Canadian wheat research has constituted socially profitable use of scarce public

1 A popular study to follow when calculating yield increase is Feyerherm, Paulsen, and Sebaugh (1984). 
resources and to what extent the social benefit from these research activities has accrued to producers and consumers.

Nalley et al. (2008) use a two-region model to evaluate the economic impact (BCR, IRR, and NPV) of the Centro Internacional de Mejoramiento de Maíz y Trigo (CIMMYT) wheat breeding program on producers and consumers (flour millers) in Mexico and the world. They include important producers like the United States, the European Union, Canada, Argentina, and Australia, as well as important importers like China and Japan. They estimate that in Mexico, producers gained an average of \$1.88 million (2002 dollars) per year from 1990 to 2002 by growing wheat varieties developed and released by CIMMYT, whereas producers outside of Mexico lost an average of $\$ 0.478$ million. Consumers in Mexico gained an average of $\$ 0.004$ million per year from 1990 to 2002, while consumers outside of Mexico gained an average of \$0.477 million per year. Heisey, Lantican, and Dubin (2002) use a constant elasticity of substitution production function to illustrate potential changes in wheat yield in farmers' fields, as well as changes in economic benefits that may be associated with an increase in experimental wheat yields. They study 36 developing countries. They estimate that returns to international wheat breeding research are $\$ 1.6$ billion to $\$ 6$ billion in annual benefits given a total investment of $\$ 150$ million per year.

Some studies have focused on how to correctly attribute the benefits and costs of the development of new crop varieties (Alston and Pardey, 2001; Pardey et al., 2004, 2006). There are several difficulties in determining the attribution of benefits of varietal improvement. For example, specific sources of new crop varieties are not always known, and defining the relevant counterfactual is challenging (Pardey et al., 2006). Identifying the relevant costs of research is also not trivial. In this article, we use the last-cross rule (Pardey et al., 2006) for the attribution of benefits; thus, we assume that all the credit for varietal improvement goes to the breeder, in this case the WSU wheat breeding programs.

Our work complements and contributes to the literature by looking at the different wheat classes independently, assuming that they are differentiated products, and by calculating welfare effects for the different regions (Washington, Oregon, and Idaho) using wheat varieties developed by WSU. We are able to calculate the spillover effects onto Oregon and Idaho. These new results provide evidence of the value of the WSU wheat breeding programs for producers and consumers, not only in Washington but also in Oregon, Idaho, the United States, and the ROW.

\section{Background}

Wheat ranks second in value among all commodities in Washington. In the United States, Washington is the fourth-largest producer of wheat. Washington is one of the largest wheat exporting states, with $85 \%$ to $90 \%$ of its crop 
being exported (Washington Grain Commission, 2014). Washington's share of world wheat, however, is not large enough to affect world wheat prices. Soft white wheat is primarily grown in Washington because of favorable growing conditions. Wheat varieties in Washington are always being adapted to counteract disease and pest issues that affect producers' yield, such as fungi and insects, as well as to meet producer demand for higher-yielding varieties.

Wheat breeding programs are important to producers and consumers. In addition to helping producers by increasing yield and/or quality, new varieties should also maintain or improve consumer-desired characteristics, such as milling properties and the characteristics required for good-quality bread, cakes, cookies, or pasta, depending on the specific wheat class. However, it is not always easy to justify increased expenditure in wheat breeding research. One reason is the long period of time from the beginning of the trials to the adoption of these varieties by growers. ${ }^{2}$ Another reason is the fact that growers do not buy seed every year but save some of the harvested grain to plant the following year or years (Heisey, Lantican, and Dubin, 2002).

The Crop and Soil Sciences Department at WSU has several plant breeding programs, one of which is wheat. The wheat research program at WSU is funded by a mix of state and federal funds, as well as contributions from the Washington Wheat Commission. ${ }^{3}$ Varieties developed by the WSU wheat breeding programs account for the majority of the wheat acreage in the state (Jones, 2006).

Table A1 in the Appendix shows the number of acres planted to WSU varieties in Washington, Oregon, and Idaho by wheat class from 2002 to 2011, as well as the acres to other varieties and the total number of acres. We see variation in the number of acres by origin and class over time. The main wheat class planted in eastern Washington is soft white wheat. In 2002, 74\% of soft white wheat acres were planted to varieties developed by WSU, compared with $61 \%$ in 2006 and $46 \%$ in 2011.4

Wheat is not a homogeneous product. The agronomic characteristics of the different varieties and consumer preferences determine the end use of wheat, making the different wheat classes differentiated products. For example, flour made from hard wheat is mainly used for bread, soft wheat flour is mainly used for cakes and cookies, and durum wheat flour is mainly used for pasta. The United States produces five major wheat classes: hard red winter (HRW), hard red spring (HRS), soft red winter (SRW), soft white winter (SWW), and durum wheat (DUR). Production of the different classes of wheat in the United States is highly segregated. HRW is grown mainly in Kansas and Oklahoma (central plains), HRS and DUR are grown mainly in North Dakota (northern

2 It can take from 7 to 12 years to develop and market a new wheat variety.

3 Funding levels vary by year and by source.

4 Our data end in 2011 because that is the last year National Agricultural Statistics Service collected data on planted acres by variety. 
plains), SRW is produced in the Corn Belt and Southern states, and SWW is grown in the Pacific Northwest, Michigan, and New York (Koo and Taylor, 2006). Given the limited substitutability for milling purposes among these wheat classes (Marsh, 2005; Mulik and Koo, 2006), it is important to analyze these different classes on their own when studying wheat for the United States. We specifically model each wheat class independently and then subdivide the classes corresponding to varieties developed at WSU into seven different regions. For Washington, Oregon, and Idaho, we subdivide each state into varieties developed by WSU and Other, and the rest of the United States is comprised by the other region. We divide consumption for each class between domestic consumption and exports.

\section{Model}

We follow Alston, Norton, and Pardey (1995) in the development of our theoretical equilibrium displacement model. The model developed in Alston, Norton, and Pardey (1995) is also similar to the ones presented in Brennan, Godyn, and Johnston (1989), Byerlee and Traxler (1995), Edwards and Freebairn (1984), and Voon and Edwards (1992), and it has been used in most studies measuring economic surplus of agricultural research (Barkley, 1997; Crespi et al., 2005; Heisey, Lantican, and Dubin, 2002; Nalley, Barkley, and Chumley, 2008; Nalley et al., 2008; etc.). Alston, Norton, and Pardey (1995) provide a structured, detailed, and well-written overview of the methods used for economic surplus estimation, as well as the methods for agricultural research evaluation and priority setting.

Figure 1 presents a flowchart overview of our model. We include production of each wheat class in the United States and consumption of each U.S. wheat class in the United States and the ROW (exports) to get a multiproduct model. Furthermore, we subdivide the wheat classes for which WSU wheat breeding programs have developed varieties (HRW, HRS, and SWW) into Washington, Oregon, Idaho, and Other States to obtain a multiregion model, in which each state studied is further divided into production of WSU varieties and Other (WAWSU, WA-Other, OR-WSU, OR-Other, ID-WSU, and ID-Other). In this way, we allow for spillover effects to Idaho and Oregon. ${ }^{5}$ We also incorporate crosscommodity price effects to allow for limited substitution in demand among wheat classes. Because we are only interested in simulating the welfare effects of yield improvements in WSU-developed varieties, we hold all other yield improvements

5 We do not consider spillover effects to the rest of the world. Given the time frame of this study, 2002-2011, we consider this assumption valid. 


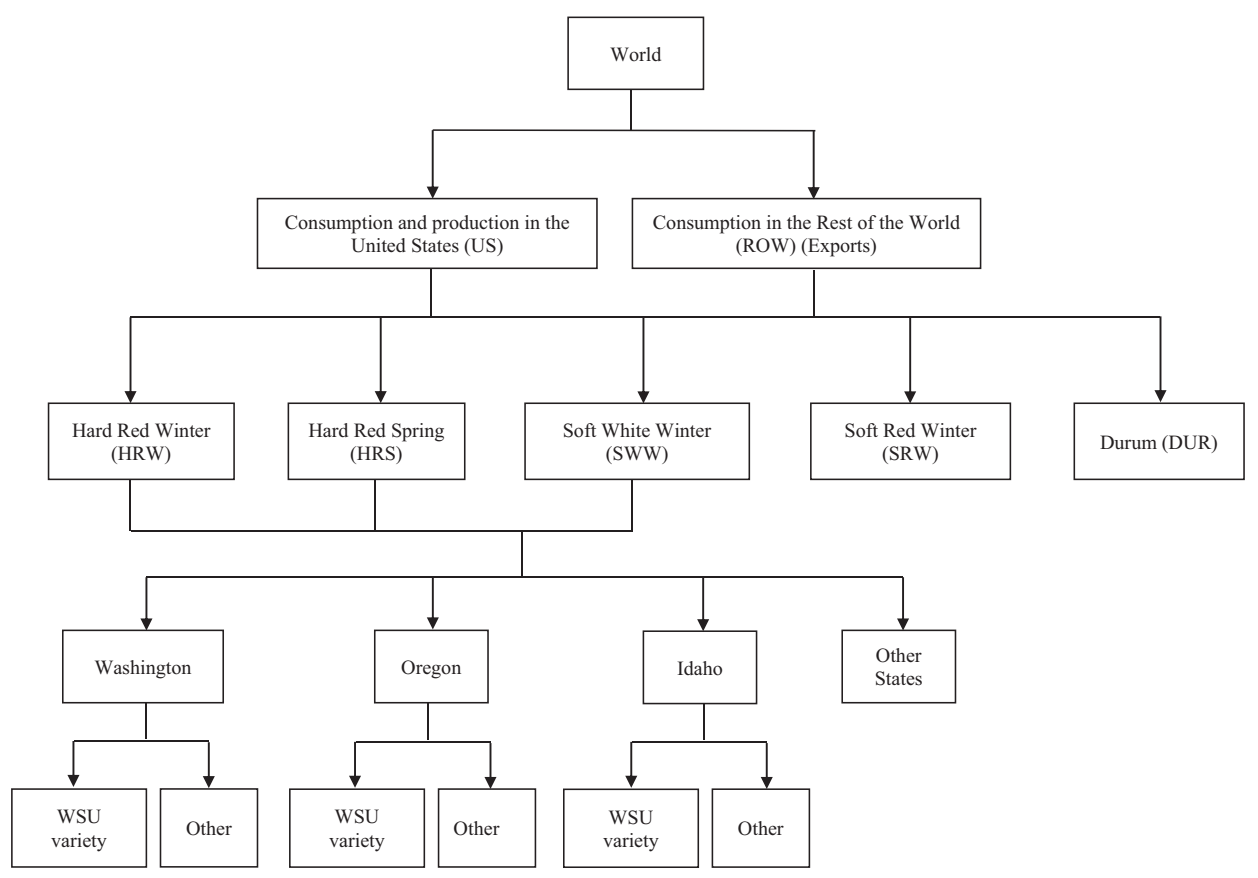

Figure 1. Flow Chart Overview of the WSU Wheat Breeding Programs Model

constant, including improvements because of technology, management practices, and other wheat breeding programs. ${ }^{6}$

First, we obtain the equilibrium prices and quantities for each wheat class, region, and subregion given a supply shift because of the yield improvement in WSU varieties. We then calculate the changes in consumer, producer, and total surplus for each wheat class and region within the United States, as well as for consumers of U.S. wheat in the ROW associated with a change in price because of a shift in the supply curve for the regions using varieties developed at WSU. We assume that the supply shift is caused by yield improvements $(J)$ by using varieties developed by the WSU wheat breeding programs, holding potential improvements by other research programs and technology constant. The supply shift parameter, $K$, is calculated as the yield increase or improvement by WSU varieties divided by the price elasticity of supply, $K=J / \varepsilon$ (Alston, Norton, and Pardey, 1995, p. 339). We use the breeder contributions to yield by wheat class from Michalski (2012) as our measure of yield increase because of WSU varieties.

The specific supply, demand, and export equations in terms of relative changes and elasticities are the following:

6 It should be noted that other states could be using wheat varieties with similar yield improvements, and thus, spillover effects may wash out once other yield improvements are considered. 
(1) $E\left(Q_{i, a}\right)=\varepsilon_{i}\left[E\left(P_{i}\right)+K_{i, a}\right], i=H R W, H R S, S W W ; a=W A-W S U, O R-W S U$, ID-WSU

(2) $E\left(Q_{i, b}\right)=\varepsilon_{i}\left[E\left(P_{i}\right)\right], b=$ WA-Other, OR-Other, ID-Other, Other States

(3) $E\left(Q_{j}\right)=\varepsilon_{j}\left[E\left(P_{j}\right)\right], j=S R W, D U R$

(4) $E\left(C_{n}\right)=\sum_{c} \eta_{n c}\left[E\left(P_{c}\right)\right], n, c=H R W, H R S, S W W, S R W, D U R$

(5) $E\left(X_{n}\right)=\eta_{R O W}\left[E\left(P_{n}\right)\right], n=H R W, H R S, S W W, S R W, D U R$

where $E$ denotes relative changes, that is, $E(Z)=d Z / Z=d \ln Z ; Q$ denotes the quantity of wheat supplied by the corresponding regions; $P$ denotes the price for wheat; $K$ denotes the vertical shift of the supply curve; $\varepsilon$ denotes the price elasticity of supply; $C$ denotes the quantity of wheat demanded by class; $X$ denotes exports by class; $\eta_{n c}$ denotes the own- and cross-price elasticity of demand for the wheat classes; and $\eta_{R O W}$ denotes the price elasticity of demand for wheat in the ROW. ${ }^{7}$

Given that prices among wheat classes are not the same, we have a market equilibrium condition for each wheat class. Equation (6) corresponds to the equilibrium condition for HRW, HRS, and SWW classes; and equation (7), to SRW and DUR:

(6) $\sum_{d} s s_{d} E\left(Q_{d}\right)=E\left(C_{i}\right)+E\left(X_{i}\right), d=W A-W S U$, WA-Other, OR-WSU, OROther, ID-WSU, ID-Other; $i=H R W, H R S, S W W$

(7) $E\left(Q_{j}\right)=E\left(C_{j}\right)+E\left(X_{j}\right), j=S R W, D U R$

where $s s_{d}$ represents the supply share $\left(s s_{d}=Q_{d} / \sum_{d} Q_{d}\right)$ for each region $d$ producing HRW, HRS, and SWW.

We solve the system of equations (1-7) to find the relative change in prices for each wheat class and the new quantity supplied, quantity consumed in the United States, and quantity exported for each wheat class after the shift in supply. Finally, we calculate changes in consumer, producer, and total surplus for each region and wheat class.

Change in producer surplus (PS) for each region and wheat class is calculated as in equations (8) and (9). Change in consumer surplus (CS) for each wheat class is calculated as in equation (10). Change in consumer surplus for consumers outside of the United States (consumer surplus for exports, CSE) for each wheat class is calculated as in equation (11). Finally, change in total surplus for each wheat class is calculated as in equation (12).

(8) $\Delta P S_{i, a}=P_{i} Q_{i, a}\left[E\left(P_{i}\right)+K_{i, a}\right]\left[1+0.5 E\left(Q_{i, a}\right)\right], i=H R W, H R S, S W W ; a=$ WA-WSU, OR-WSU, ID-WSU

(9) $\Delta P S_{j}=P_{j} Q_{j}\left[E\left(P_{j}\right)\right]\left[1+0.5 E\left(Q_{j}\right)\right], j=S R W, D U R$

(10) $\Delta C S_{n}=-P_{n} C_{n}\left[E\left(P_{n}\right)\right]\left[1+0.5 E\left(C_{n}\right)\right], n=H R W, H R S, S W W, S R W, D U R$

(11) $\Delta C S E_{n}=-P_{n} X_{n}\left[E\left(P_{n}\right)\right]\left[1+0.5 E\left(X_{n}\right)\right], n=H R W, H R S, S W W, S R W, D U R$

(12) $\Delta T S_{n}=\Delta P S_{n}+\Delta C S_{n}+\Delta C S E_{n}, n=H R W, H R S, S W W, S R W, D U R$

7 Unfortunately, we do not have estimates of the elasticity of demand for each U.S. wheat class in the rest of the world. We use the wheat elasticity of demand in Nalley et al. (2008). 
Table 1. Variable and Parameter Definition and Source

\begin{tabular}{|c|c|c|}
\hline $\begin{array}{l}\text { Variable/ } \\
\text { Parameter }\end{array}$ & Definition & Source \\
\hline$E(Z)$ & Relative change for variable $Z$ & $E(Z)=d Z / Z=d \ln Z$ \\
\hline$Q$ & Quantity produced, annual by wheat class & $\begin{array}{l}\text { U.S. Department of Agriculture (USDA) } \\
\text { National Agricultural Statistics Service } \\
\text { (Washington, Oregon, and Idaho) and } \\
\text { USDA Economic Research Service } \\
\text { Wheat Yearbook Tables (United States) }\end{array}$ \\
\hline C & Quantity consumed, annual, by wheat class & $\begin{array}{l}\text { USDA Economic Research Service Wheat } \\
\text { Yearbook Tables }\end{array}$ \\
\hline$X$ & Quantity exported, annual, by wheat class & $\begin{array}{l}\text { USDA Economic Research Service Wheat } \\
\text { Yearbook Tables }\end{array}$ \\
\hline$P$ & Price, annual, by wheat class & $\begin{array}{l}\text { USDA Economic Research Service Wheat } \\
\text { Yearbook Tables }\end{array}$ \\
\hline$J$ & $\begin{array}{l}\text { Yield increase because of WSU wheat } \\
\text { breeding programs }\end{array}$ & $\begin{array}{c}0.29 \% \text { for SWW, } 0.32 \% \text { for HRW, and } \\
0.32 \% \text { for HRS (Michalski, 2012) }\end{array}$ \\
\hline K & Vertical shift of the supply curve & $K=J / \varepsilon$ \\
\hline$\varepsilon$ & Price elasticity of supply & United States $=0.22($ DeVuyst et al., 2001) \\
\hline$\eta$ & Price elasticity of demand & $\begin{array}{l}\text { U.S. wheat classes = Table A2 (Marsh, } \\
\text { 2005) } \\
\text { ROW }=-0.53 \text { (Nalley et al., 2008) }\end{array}$ \\
\hline ss & $\begin{array}{l}\text { Supply share for each region } d \text { producing } \\
\text { HRW, HRS, and SWW }\end{array}$ & $\begin{array}{l}s s_{d}=Q_{d} / \sum_{d} Q_{d} \\
\quad d=W A-W S U, W A-O t h e r, \text { OR-WSU, } \\
\text { OR-Other, ID-WSU, ID-Other }\end{array}$ \\
\hline$P S$ & Producer surplus & Equations (8) and (9) \\
\hline$C S$ & Consumer surplus & Equation (10) \\
\hline CSE & Consumer surplus for exports & Equation (11) \\
\hline$T S$ & Total surplus & Equation (12) \\
\hline
\end{tabular}

Note: HRS, hard red spring; HRW, hard red winter; ROW, rest of the world, SWW, soft white winter; WSU, Washington State University.

where $P$ represents the initial price, and $Q, C$, and $X$ represent the initial producer, consumer, and export quantities, respectively. In this way, total surplus from the research-induced supply shift corresponds to the area below the demand curve and between the two supply curves. This area represents the sum of the cost saving because of the yield increase and the economic surplus because of the increment to production and consumption.

A main limitation of this model is that it assumes only a parallel shift in the supply curve. Additionally, it applies linear demand and supply functions to provide at best a first-order approximation of economic surplus. The model, however, is still general and flexible enough to accommodate a wide range of different market structures and characteristics. All variables and parameters used in the model are presented in Table 1, including their definition and source. 


\section{Data}

Annual wheat production data for Washington, Oregon, and Idaho from 2002 to 2011 are available through the U.S. Department of Agriculture (USDA) National Agricultural Statistics Service (NASS) website (USDA-NASS, 2014). Detailed information on acreage by variety by state over time was obtained through the NASS Statistical Bulletins by State (USDA-NASS Idaho, 2014; USDA-NASS Oregon, 2014; USDA-NASS Washington, 2014). ${ }^{8}$ Annual data on price, production, and consumption for the United States and the world are available through the USDA Economic Research Service (ERS) Wheat Yearbook Tables (USDA-ERS, 2014). Annual prices were deflated to reflect 2011 dollars using the U.S. producer price index (PPI) obtained through the Bureau of Labor Statistics (BLS) website (U.S. Department of Labor, BLS, 2014). The PPI was adjusted to represent 2011 dollars by changing the base year to 2011. Supply and demand elasticities are obtained from the literature as discussed in the "Results" section.

Firsthand consumption data are not available for Washington, Oregon, and Idaho. For these states, we calculated consumption proportionally to the state's population based on consumption for the whole United States. Population data for the United States, Washington, Oregon, and Idaho were obtained through the Census Bureau website (U.S. Census Bureau, 2014).

We use an improved empirical measure of breeder contributions to yield from Michalski (2012) as the yield increase for WSU varieties. Michalski uses unique data provided by WSU's Wheat Variety Testing program that has comprehensive wheat variety test plot data from 1979 through 2011. The test plot data are populated by many varieties that have been in continuous use, such as STEPHENS and NUGAINES, since 1979 through present. These long histories of specific varieties allow a comparison between yield improvements because of improved farm management versus yield improvements because of breeding, as in the example of STEPHENS where today's yield averages nearly twice the yield obtained in 1979. Michalski (2012) combines data from the WSU wheat variety test program with spatially and temporally interpolated historical weather records to analyze Washington wheat variety performance across time and geography. He estimates breeder contributions to yield by regressing yield for each wheat variety while controlling for location, temperature, weather variables, a continuous time variable represented by the harvest year (applies a slope representing improvements because of farm management), and binary variables for each variety (representing differences in performance between varieties, i.e., shifts in intercept). In the analysis, each variety is forced to share the same slope while the variety binary variables compare average yield differences between

8 Data on planted acres by variety for Idaho were not collected in 2009. We interpolated the values using the ipolate command in Stata (StataCorp, 2013). 
varieties. Ordering variety yield by release year allows a trend estimate on breeder contributions to gains in yield. A key assumption in this analysis takes a wheat variety to be genetically constant year over year. If the same variety is observed improving in yield year over year, then that measurable improvement, controlled for location and weather conditions, is attributable to on-farm management improvements. Likewise, a difference in yield between varieties, controlling for location and weather conditions, allows a measure of variety improvements over time. We use the difference in yield between varieties as our measure of yield improvement because of WSU wheat breeding programs. Michalski (2012) estimates an increase of 0.28 bushels per acre for each year for SWW, 0.213 for HRW, and 0.15 for HRS, on average. Given the average yield of 96.5 bushels per acre for SWW, 66.7 for HRW, and 46.5 for HRS from 2002 to 2011, the yield increase $(J)$ attributed to WSU wheat breeding programs is $0.29 \%$ for SWW, $0.32 \%$ for HRW, and $0.32 \%$ for HRS. ${ }^{9}$

We calculate quantity produced for Washington, Oregon, and Idaho for varieties developed by WSU and others using the acreage data by variety by state over time from NASS. The varieties were matched to a cultivar list and cross-reference guide put together by Dr. Craig Morris from the Western Wheat Quality Laboratory, USDA (Morris, 2007). This reference guide contains information regarding the variety name, release date, source, and origin, among others. The list was complemented with Internet searches for the varieties not included in the list. Even though this list is not comprehensive, it gives a lower bound on the number of acres planted to WSU varieties in Washington, Oregon, and Idaho. We multiplied acres times yield by wheat type to get quantity produced for each wheat class and subregion.

To complete the economic analysis, we use data on expenditures for WSU wheat breeding research obtained from the WSU College of Agriculture, Human, and Natural Resource Sciences for 2001 to 2011. Specifically, expenditures represent all accounts related to wheat breeding research for 2001 to 2011. To incorporate the lagged effect of wheat breeding research, we include wheat breeding research expenditure from 1993 to 2011 . We use actual data from 1955 to 1983 and from 2001 to 2011 to create a predictive model and then interpolate expenditures for the missing period 1993 to 2000.

\section{Results}

Changes in consumer, producer, and total surplus because of a shift in the supply curve for producers are analyzed across WSU wheat varieties. We assume that the shift in the supply curve is because of the yield improvement provided by using WSU wheat varieties. We assume that the price elasticity of supply for the

9 This approach is similar to Nalley, Barkley, and Chumley (2008) and Nalley, Barkley, and Featherstone (2010). 
United States is 0.22 (DeVuyst et al., 2001) and the price elasticity of demand for the ROW is -0.53 (Nalley et al., 2008). ${ }^{10}$ The own- and cross-price elasticities of demand for the U.S. wheat classes are presented in the Appendix in Table A2 (Marsh, 2005). Table A3 contains quantity produced by class in million bushels; Table A4 contains quantity produced by region in million bushels; and Table A5 contains quantity consumed and exports in million bushels, and price in 2011 dollars per bushel by wheat class (see Appendix). We use General Algebraic Modeling System (GAMS Development Corporation, 2011) to solve equations (1)-(7) for the equilibrium prices and quantities using the MILES solver for mixed complementarity problems.

Changes in producer, consumer, and total surplus by wheat class are presented in Table 2, changes in producer surplus by region in Table 3 , and changes in consumer and total surplus in Table 4. These changes in surplus are in 2011 million dollars. Tables 5 and 6 present surplus changes in 2011 dollars per acre, and Table 7 presents surplus changes in 2011 dollars per capita. Our results suggest that producer surplus and consumer surplus from the researchinduced supply shift because of WSU wheat breeding programs have increased for producers using WSU varieties and consumers in all regions. The specific increase in surplus depends on the region and level of production (Table 3). The largest producer surplus increase for WSU varieties, \$2.968 million to \$5.107 million per year, is observed for SWW in Washington, which is the majority of the wheat grown in the Pacific Northwest. Producer surplus increases for WSU varieties of SWW in Idaho range from $\$ 0.402$ million to $\$ 1.094$ million per year. In Oregon, producer surplus increases by $\$ 0.143$ million to $\$ 0.506$ million per year for WSU varieties of SWW. Producers using WSU varieties gain because of the increased yield. Yield increases translate into increases in quantity supplied and decreases in prices. Even with lower equilibrium prices, producers using WSU varieties still observe large gains because of higher yield.

Most producers using other varieties experience a decrease in surplus, except for producers of HRS. Decrease in producer surplus for other varieties for HRW and SWW ranges from $\$ 1,000$ to $\$ 333,000$ per year for Washington, $\$ 4,000$ to $\$ 250,000$ per year for Idaho, and almost zero to $\$ 312,000$ per year for Oregon. Producer surplus for other varieties of HRS changes very little ranging from a decrease of $\$ 4,000$ to an increase of $\$ 2,000$ because of cross-price effects among wheat classes. Producer surplus for SRW decreases by $\$ 13,000$ to $\$ 34,000$ per year, whereas producer surplus for DUR increases by $\$ 11,000$ to $\$ 26,000$ per year because of the cross-price effects among wheat classes. At an aggregate level, U.S. producer surplus increases by $\$ 3.560$ million to $\$ 6.146$ million per year (Table 2). Producer surplus for other varieties mostly decreases given the lower prices and the fact that producers do not benefit from the higher yield of

10 We conduct a sensitivity analysis for elasticity estimates ranging from 0.1 to 1 for the price elasticity of supply for the United States and for the price elasticity of demand for the rest of the world. 
Table 2. Surplus Changes by Wheat Class (2011 Million Dollars)

\begin{tabular}{|c|c|c|c|c|c|c|c|}
\hline Surplus Changes & Year & HRW & HRS & SWW & SRW & DUR & All \\
\hline \multirow[t]{10}{*}{ Producer } & 2002 & 0.161 & 0.222 & 5.192 & -0.028 & 0.026 & 5.574 \\
\hline & 2003 & 0.068 & 0.235 & 5.254 & -0.028 & 0.026 & 5.555 \\
\hline & 2004 & 0.164 & 0.286 & 4.756 & -0.025 & 0.020 & 5.202 \\
\hline & 2005 & 0.127 & 0.192 & 3.809 & -0.019 & 0.019 & 4.128 \\
\hline & 2006 & 0.332 & 0.305 & 3.721 & -0.020 & 0.011 & 4.349 \\
\hline & 2007 & 0.815 & 0.418 & 4.911 & -0.023 & 0.026 & 6.146 \\
\hline & 2008 & 0.453 & 0.403 & 3.435 & -0.034 & 0.022 & 4.279 \\
\hline & 2009 & 0.274 & 0.413 & 2.872 & -0.020 & 0.021 & 3.560 \\
\hline & 2010 & 0.292 & 0.495 & 3.858 & -0.013 & 0.020 & 4.653 \\
\hline & 2011 & 0.367 & 0.569 & 3.640 & -0.021 & 0.011 & 4.566 \\
\hline \multirow[t]{10}{*}{ Consumer } & 2002 & 0.242 & -0.050 & 2.044 & 0.023 & -0.037 & 2.222 \\
\hline & 2003 & 0.209 & -0.058 & 1.977 & 0.022 & -0.032 & 2.118 \\
\hline & 2004 & 0.208 & -0.026 & 1.782 & 0.018 & -0.023 & 1.959 \\
\hline & 2005 & 0.182 & -0.039 & 1.337 & 0.014 & -0.024 & 1.471 \\
\hline & 2006 & 0.257 & 0.015 & 1.679 & 0.016 & -0.025 & 1.942 \\
\hline & 2007 & 0.508 & 0.055 & 2.287 & 0.024 & -0.046 & 2.828 \\
\hline & 2008 & 0.315 & 0.016 & 1.202 & 0.020 & -0.027 & 1.526 \\
\hline & 2009 & 0.224 & 0.015 & 1.103 & 0.013 & -0.023 & 1.332 \\
\hline & 2010 & 0.341 & 0.017 & 1.508 & 0.014 & -0.024 & 1.856 \\
\hline & 2011 & 0.331 & 0.090 & 1.420 & 0.015 & -0.022 & 1.833 \\
\hline \multirow[t]{10}{*}{ Total } & 2002 & 0.403 & 0.172 & 7.236 & -0.004 & -0.011 & 7.796 \\
\hline & 2003 & 0.278 & 0.177 & 7.231 & -0.007 & -0.006 & 7.673 \\
\hline & 2004 & 0.372 & 0.260 & 6.538 & -0.007 & -0.002 & 7.161 \\
\hline & 2005 & 0.310 & 0.153 & 5.146 & -0.005 & -0.005 & 5.599 \\
\hline & 2006 & 0.589 & 0.320 & 5.400 & -0.004 & -0.014 & 6.291 \\
\hline & 2007 & 1.323 & 0.473 & 7.198 & 0.000 & -0.020 & 8.974 \\
\hline & 2008 & 0.767 & 0.419 & 4.637 & -0.014 & -0.005 & 5.805 \\
\hline & 2009 & 0.499 & 0.428 & 3.975 & -0.007 & -0.003 & 4.892 \\
\hline & 2010 & 0.633 & 0.512 & 5.367 & 0.001 & -0.004 & 6.509 \\
\hline & 2011 & 0.698 & 0.659 & 5.060 & -0.006 & -0.011 & 6.399 \\
\hline
\end{tabular}

Note: DUR, durum wheat; HRS, hard red spring; HRW, hard red winter; SRW, soft red winter; SWW, soft white winter.

using WSU varieties. This decreased surplus, however, is quite small and almost insignificant in economic terms.

Changes in consumer surplus are positive in all regions, with the magnitude of the increase depending on the number of consumers in each region (Table 4). Changes in consumer surplus by wheat class, however, increase or decrease depending on the class. Consumer surplus increases by $\$ 11,000$ to $\$ 21,000$ per year in Washington, \$501,000 to \$984,000 per year in the United States, and \$1.332 million to $\$ 2.828$ million per year in all regions (domestic consumption and exports of U.S. wheat). Consumer surplus increases from $\$ 182,000$ to $\$ 508,000$ for HRW, $\$ 1.103$ million to $\$ 2.287$ million for SWW, and $\$ 13,000$ to $\$ 24,000$ for SRW (domestic consumption and exports). Consumer surplus decreases from 
Table 3. Producer Surplus Changes by Region (2011 Million Dollars)

\begin{tabular}{|c|c|c|c|c|c|c|c|c|}
\hline \multirow[b]{2}{*}{ Region } & \multirow[b]{2}{*}{ Year } & \multicolumn{2}{|c|}{ HRW } & \multicolumn{2}{|c|}{ HRS } & \multicolumn{2}{|c|}{ SWW } & \multirow[b]{2}{*}{ All } \\
\hline & & WSU & Other & WSU & Other & WSU & Other & \\
\hline \multirow[t]{10}{*}{ Washington } & 2002 & 0.379 & -0.001 & 0.183 & $5.0 \mathrm{E}-04$ & 4.817 & -0.228 & 5.150 \\
\hline & 2003 & 0.320 & -0.001 & 0.176 & 0.001 & 5.107 & -0.181 & 5.421 \\
\hline & 2004 & 0.378 & -0.001 & 0.231 & $3.2 \mathrm{E}-04$ & 4.623 & -0.193 & 5.039 \\
\hline & 2005 & 0.318 & -0.001 & 0.126 & $4.2 \mathrm{E}-04$ & 3.823 & -0.186 & 4.080 \\
\hline & 2006 & 0.580 & -0.002 & 0.254 & $-3.3 \mathrm{E}-04$ & 3.944 & -0.252 & 4.523 \\
\hline & 2007 & 1.276 & -0.007 & 0.252 & -0.001 & 5.099 & -0.333 & 6.287 \\
\hline & 2008 & 0.815 & -0.002 & 0.242 & $-3.1 \mathrm{E}-04$ & 3.590 & -0.209 & 4.435 \\
\hline & 2009 & 0.547 & -0.002 & 0.294 & $-3.2 \mathrm{E}-04$ & 2.968 & -0.203 & 3.603 \\
\hline & 2010 & 0.646 & -0.003 & 0.364 & $-3.1 \mathrm{E}-04$ & 4.388 & -0.280 & 5.114 \\
\hline & 2011 & 0.686 & -0.004 & 0.551 & -0.003 & 4.278 & -0.296 & 5.213 \\
\hline \multirow[t]{10}{*}{ Idaho } & 2002 & $7.5 \mathrm{E}-08$ & -0.004 & $8.6 \mathrm{E}-08$ & 0.002 & 1.094 & -0.248 & 0.844 \\
\hline & 2003 & $6.8 \mathrm{E}-08$ & -0.004 & $7.8 \mathrm{E}-08$ & 0.002 & 0.987 & -0.198 & 0.787 \\
\hline & 2004 & $6.5 \mathrm{E}-08$ & -0.004 & 0.023 & 0.001 & 0.886 & -0.212 & 0.694 \\
\hline & 2005 & $6.3 \mathrm{E}-08$ & -0.004 & 0.023 & 0.001 & 0.701 & -0.199 & 0.523 \\
\hline & 2006 & $8.0 \mathrm{E}-08$ & -0.006 & 0.060 & -0.001 & 0.598 & -0.195 & 0.457 \\
\hline & 2007 & $1.0 \mathrm{E}-07$ & -0.011 & 0.205 & -0.002 & 0.862 & -0.250 & 0.805 \\
\hline & 2008 & $1.1 \mathrm{E}-07$ & -0.007 & 0.175 & -0.001 & 0.578 & -0.208 & 0.537 \\
\hline & 2009 & $8.2 \mathrm{E}-08$ & -0.006 & 0.132 & -0.001 & 0.605 & -0.182 & 0.549 \\
\hline & 2010 & $1.0 \mathrm{E}-07$ & -0.006 & 0.140 & -0.001 & 0.504 & -0.216 & 0.421 \\
\hline & 2011 & $1.0 \mathrm{E}-07$ & -0.006 & 0.090 & -0.004 & 0.402 & -0.222 & 0.260 \\
\hline \multirow[t]{10}{*}{ Oregon } & 2002 & $7.5 \mathrm{E}-08$ & $-6.2 \mathrm{E}-05$ & 0.002 & $1.0 \mathrm{E}-04$ & 0.497 & -0.232 & 0.267 \\
\hline & 2003 & $6.8 \mathrm{E}-08$ & $-9.9 \mathrm{E}-05$ & $7.8 \mathrm{E}-08$ & $1.4 \mathrm{E}-04$ & 0.506 & -0.291 & 0.215 \\
\hline & 2004 & 0.015 & $-1.5 \mathrm{E}-05$ & 0.007 & $7.4 \mathrm{E}-05$ & 0.506 & -0.277 & 0.250 \\
\hline & 2005 & 0.021 & $-5.6 \mathrm{E}-05$ & 0.006 & $1.5 \mathrm{E}-04$ & 0.299 & -0.226 & 0.099 \\
\hline & 2006 & 0.020 & $-3.2 \mathrm{E}-04$ & 0.005 & $-8.1 \mathrm{E}-05$ & 0.213 & -0.209 & 0.029 \\
\hline & 2007 & 0.052 & -0.001 & 0.006 & $-2.3 \mathrm{E}-04$ & 0.380 & -0.312 & 0.125 \\
\hline & 2008 & 0.026 & $-4.5 \mathrm{E}-04$ & 0.006 & $-1.1 \mathrm{E}-04$ & 0.341 & -0.214 & 0.159 \\
\hline & 2009 & 0.007 & $-3.8 \mathrm{E}-04$ & 0.005 & $-7.6 \mathrm{E}-05$ & 0.173 & -0.188 & -0.003 \\
\hline & 2010 & $1.0 \mathrm{E}-07$ & -0.001 & 0.007 & $-1.2 \mathrm{E}-04$ & 0.159 & -0.285 & -0.120 \\
\hline & 2011 & $1.0 \mathrm{E}-07$ & -0.001 & 0.004 & -0.001 & 0.143 & -0.278 & -0.133 \\
\hline \multirow[t]{10}{*}{ Other states } & 2002 & - & -0.212 & - & 0.034 & - & -0.508 & - \\
\hline & 2003 & - & -0.246 & - & 0.056 & - & -0.675 & - \\
\hline & 2004 & - & -0.224 & - & 0.023 & - & -0.576 & - \\
\hline & 2005 & - & -0.207 & - & 0.034 & - & -0.402 & - \\
\hline & 2006 & - & -0.260 & - & -0.012 & - & -0.378 & - \\
\hline & 2007 & - & -0.494 & - & -0.043 & - & -0.536 & - \\
\hline & 2008 & - & -0.378 & - & -0.018 & - & -0.444 & - \\
\hline & 2009 & - & -0.272 & - & -0.017 & - & -0.301 & - \\
\hline & 2010 & - & -0.344 & - & -0.015 & - & -0.410 & - \\
\hline & 2011 & - & -0.309 & - & -0.068 & - & -0.388 & - \\
\hline
\end{tabular}

Note: HRS, hard red spring; HRW, hard red winter; SWW, soft white winter; WSU, Washington State University. 
Table 4. Consumer and Total Surplus Changes (2011 Million Dollars)

\begin{tabular}{|c|c|c|c|c|}
\hline \multirow[b]{2}{*}{ Year } & \multicolumn{4}{|c|}{ Change in Consumer Surplus } \\
\hline & Washington & Idaho & Oregon & United States \\
\hline 2002 & 0.017 & 0.004 & 0.010 & 0.818 \\
\hline 2003 & 0.014 & 0.003 & 0.008 & 0.661 \\
\hline 2004 & 0.012 & 0.003 & 0.007 & 0.559 \\
\hline 2005 & 0.011 & 0.002 & 0.006 & 0.501 \\
\hline 2006 & 0.014 & 0.003 & 0.008 & 0.653 \\
\hline 2007 & 0.021 & 0.005 & 0.012 & 0.984 \\
\hline 2008 & 0.013 & 0.003 & 0.008 & 0.605 \\
\hline 2009 & 0.011 & 0.003 & 0.006 & 0.516 \\
\hline 2010 & 0.013 & 0.003 & 0.008 & 0.605 \\
\hline \multirow{2}{*}{2011} & 0.013 & 0.003 & 0.007 & 0.598 \\
\hline & \multicolumn{4}{|c|}{ Change in Total Surplus } \\
\hline Year & Washington & Idaho & Oregon & United States \\
\hline 2002 & 5.167 & 0.847 & 0.277 & 6.391 \\
\hline 2003 & 5.435 & 0.790 & 0.223 & 6.216 \\
\hline 2004 & 5.050 & 0.697 & 0.257 & 5.761 \\
\hline 2005 & 4.091 & 0.526 & 0.106 & 4.629 \\
\hline 2006 & 4.537 & 0.460 & 0.037 & 5.002 \\
\hline 2007 & 6.308 & 0.810 & 0.137 & 7.131 \\
\hline 2008 & 4.448 & 0.540 & 0.166 & 4.883 \\
\hline 2009 & 3.614 & 0.552 & 0.003 & 4.076 \\
\hline 2010 & 5.127 & 0.424 & -0.113 & 5.258 \\
\hline 2011 & 5.226 & 0.263 & -0.125 & 5.164 \\
\hline
\end{tabular}

$\$ 26,000$ to $\$ 58,000$ from 2002 to 2005 and increases from $\$ 15,000$ to $\$ 90,000$ from 2006 to 2011 for HRS. Consumer surplus decreases from \$22,000 to $\$ 46,000$ for DUR. Consumers reap all the benefits of lower prices, and thus, increases in consumer surplus are dependent on the number of consumers in each region and the specific quantity consumed. When prices increase, however, consumers lose, as in the case of HRS from 2002 to 2005 and DUR.

The net effect is always positive for most regions (except Oregon in 2010 and 2011), but not for all classes. Increases in total surplus range from $\$ 3.614$ million to $\$ 6.308$ million per year for Washington, from $\$ 263,000$ to $\$ 847,000$ per year for Idaho, from $\$ 3,000$ to $\$ 277,000$ per year from 2002 to 2009 for Oregon, and from $\$ 4.076$ million to $\$ 7.131$ million per year for the United States. Total surplus decreases in Oregon for 2010 and 2011 by $\$ 113,000$ and $\$ 125,000$, as fewer acres are planted to WSU varieties. Total surplus for HRW, HRS, and SWW (wheat classes that experience a yield increase because of the WSU wheat breeding programs) always increases, ranging from $\$ 0.278$ million to $\$ 1.323$ million for HRW, $\$ 153,000$ to $\$ 659,000$ for HRS, and $\$ 3.975$ million to $\$ 7.236$ million for SWW per year. Total surplus for SRW and DUR almost always decreases, although changes are very small ranging from an increase of 
Table 5. Surplus Changes by Wheat Class (2011 Dollars/Acre)

\begin{tabular}{|c|c|c|c|c|c|c|c|}
\hline Surplus Changes & Year & HRW & HRS & SWW & SRW & DUR & All \\
\hline \multirow[t]{10}{*}{ Producer } & 2002 & 0.01 & 0.01 & 1.18 & 0.00 & 0.01 & 0.09 \\
\hline & 2003 & 0.00 & 0.02 & 1.01 & 0.00 & 0.01 & 0.09 \\
\hline & 2004 & 0.01 & 0.02 & 0.94 & 0.00 & 0.01 & 0.09 \\
\hline & 2005 & 0.00 & 0.01 & 0.77 & 0.00 & 0.01 & 0.07 \\
\hline & 2006 & 0.01 & 0.02 & 0.86 & 0.00 & 0.01 & 0.08 \\
\hline & 2007 & 0.02 & 0.03 & 1.24 & 0.00 & 0.01 & 0.10 \\
\hline & 2008 & 0.01 & 0.03 & 0.77 & 0.00 & 0.01 & 0.07 \\
\hline & 2009 & 0.01 & 0.03 & 0.72 & 0.00 & 0.01 & 0.06 \\
\hline & 2010 & 0.01 & 0.04 & 0.91 & 0.00 & 0.01 & 0.09 \\
\hline & 2011 & 0.01 & 0.05 & 0.83 & 0.00 & 0.01 & 0.08 \\
\hline \multirow[t]{10}{*}{ Consumer } & 2002 & 0.01 & 0.00 & 0.46 & 0.00 & -0.01 & 0.04 \\
\hline & 2003 & 0.01 & 0.00 & 0.38 & 0.00 & -0.01 & 0.03 \\
\hline & 2004 & 0.01 & 0.00 & 0.35 & 0.00 & -0.01 & 0.03 \\
\hline & 2005 & 0.01 & 0.00 & 0.27 & 0.00 & -0.01 & 0.03 \\
\hline & 2006 & 0.01 & 0.00 & 0.39 & 0.00 & -0.01 & 0.03 \\
\hline & 2007 & 0.02 & 0.00 & 0.58 & 0.00 & -0.02 & 0.05 \\
\hline & 2008 & 0.01 & 0.00 & 0.27 & 0.00 & -0.01 & 0.02 \\
\hline & 2009 & 0.01 & 0.00 & 0.27 & 0.00 & -0.01 & 0.02 \\
\hline & 2010 & 0.01 & 0.00 & 0.36 & 0.00 & -0.01 & 0.03 \\
\hline & 2011 & 0.01 & 0.01 & 0.32 & 0.00 & -0.02 & 0.03 \\
\hline \multirow[t]{10}{*}{ Total } & 2002 & 0.01 & 0.01 & 1.65 & 0.00 & 0.00 & 0.13 \\
\hline & 2003 & 0.01 & 0.01 & 1.39 & 0.00 & 0.00 & 0.12 \\
\hline & 2004 & 0.01 & 0.02 & 1.30 & 0.00 & 0.00 & 0.12 \\
\hline & 2005 & 0.01 & 0.01 & 1.04 & 0.00 & 0.00 & 0.10 \\
\hline & 2006 & 0.02 & 0.02 & 1.25 & 0.00 & -0.01 & 0.11 \\
\hline & 2007 & 0.04 & 0.04 & 1.81 & 0.00 & -0.01 & 0.15 \\
\hline & 2008 & 0.02 & 0.03 & 1.03 & 0.00 & 0.00 & 0.09 \\
\hline & 2009 & 0.02 & 0.03 & 0.99 & 0.00 & 0.00 & 0.08 \\
\hline & 2010 & 0.02 & 0.04 & 1.27 & 0.00 & 0.00 & 0.12 \\
\hline & 2011 & 0.02 & 0.06 & 1.15 & 0.00 & -0.01 & 0.12 \\
\hline
\end{tabular}

Note: DUR, durum wheat; HRS, hard red spring; HRW, hard red winter; SRW, soft red winter; SWW, soft white winter.

$\$ 1,000$ to a decrease of $\$ 14,000$ for SRW, and a decrease of $\$ 2,000$ to $\$ 20,000$ for DUR per year, making these changes almost insignificant in economic terms. It should be noted that these two classes are not part of the WSU wheat breeding programs, and thus any yield improvement to these wheat classes is held constant. The decrease in total surplus for SRW and DUR is quite small compared with the overall benefits, as represented in the total surplus changes for the United States as an aggregate and the world. Net effects reflect the balance between consumers, producers using WSU varieties, and producers using other varieties, given that in general surplus increases for the first two groups but decreases for the third one. We observe positive net effects if the number of consumers and producers using WSU varieties outweighs producers using other varieties. 
Table 6. Producer Surplus Changes by Region (2011 Dollars/Acre)

\begin{tabular}{|c|c|c|c|c|c|c|c|c|}
\hline \multirow[b]{2}{*}{ Region } & \multirow[b]{2}{*}{ Year } & \multicolumn{2}{|c|}{ HRW } & \multicolumn{2}{|c|}{ HRS } & \multicolumn{2}{|c|}{ SWW } & \multirow[b]{2}{*}{ All } \\
\hline & & WSU & Other & WSU & Other & WSU & Other & \\
\hline \multirow[t]{10}{*}{ Washington } & 2002 & 4.33 & -0.02 & 3.71 & 0.00 & 3.80 & -0.52 & 2.10 \\
\hline & 2003 & 4.43 & -0.02 & 3.18 & 0.00 & 3.96 & -0.46 & 2.26 \\
\hline & 2004 & 4.38 & -0.02 & 3.53 & 0.00 & 3.84 & -0.42 & 2.16 \\
\hline & 2005 & 4.20 & -0.02 & 3.05 & 0.00 & 3.19 & -0.35 & 1.79 \\
\hline & 2006 & 5.21 & -0.03 & 4.02 & 0.00 & 3.95 & -0.39 & 1.98 \\
\hline & 2007 & 6.43 & -0.03 & 5.63 & 0.00 & 6.34 & -0.56 & 2.90 \\
\hline & 2008 & 5.94 & -0.02 & 4.83 & 0.00 & 4.41 & -0.30 & 1.94 \\
\hline & 2009 & 4.82 & -0.02 & 4.04 & 0.00 & 3.80 & -0.29 & 1.57 \\
\hline & 2010 & 7.07 & -0.02 & 5.44 & 0.00 & 5.44 & -0.39 & 2.19 \\
\hline & 2011 & 7.53 & -0.03 & 7.62 & -0.01 & 6.01 & -0.35 & 2.19 \\
\hline \multirow[t]{10}{*}{ Idaho } & 2002 & 0.00 & -0.03 & 0.00 & 0.01 & 5.04 & -0.69 & 0.73 \\
\hline & 2003 & 0.00 & -0.02 & 0.00 & 0.01 & 4.87 & -0.57 & 0.66 \\
\hline & 2004 & 0.00 & -0.02 & 5.58 & 0.00 & 5.16 & -0.57 & 0.56 \\
\hline & 2005 & 0.00 & -0.02 & 5.00 & 0.01 & 4.34 & -0.47 & 0.42 \\
\hline & 2006 & 0.00 & -0.03 & 5.86 & 0.00 & 4.67 & -0.46 & 0.36 \\
\hline & 2007 & 0.00 & -0.04 & 8.32 & -0.01 & 7.46 & -0.66 & 0.65 \\
\hline & 2008 & 0.00 & -0.03 & 8.28 & 0.00 & 5.90 & -0.41 & 0.38 \\
\hline & 2009 & 0.00 & -0.02 & 6.91 & 0.00 & 5.22 & -0.40 & 0.42 \\
\hline & 2010 & 0.00 & -0.03 & 8.15 & 0.00 & 6.47 & -0.46 & 0.30 \\
\hline & 2011 & 0.00 & -0.03 & 10.32 & -0.02 & 6.57 & -0.38 & 0.18 \\
\hline \multirow[t]{10}{*}{ Oregon } & 2002 & 0.00 & -0.01 & 3.11 & 0.00 & 2.75 & -0.38 & 0.28 \\
\hline & 2003 & 0.00 & -0.01 & 0.00 & 0.00 & 3.10 & -0.36 & 0.19 \\
\hline & 2004 & 3.99 & -0.02 & 3.39 & 0.00 & 3.50 & -0.38 & 0.26 \\
\hline & 2005 & 3.82 & -0.01 & 3.61 & 0.00 & 2.91 & -0.32 & 0.11 \\
\hline & 2006 & 4.17 & -0.02 & 4.02 & 0.00 & 3.16 & -0.31 & 0.03 \\
\hline & 2007 & 5.50 & -0.03 & 5.87 & 0.00 & 5.42 & -0.48 & 0.15 \\
\hline & 2008 & 6.15 & -0.02 & 5.17 & 0.00 & 4.56 & -0.32 & 0.17 \\
\hline & 2009 & 4.57 & -0.02 & 4.84 & 0.00 & 3.61 & -0.27 & 0.00 \\
\hline & 2010 & 0.00 & -0.02 & 7.11 & 0.00 & 5.28 & -0.38 & -0.13 \\
\hline & 2011 & 0.00 & -0.03 & 8.60 & -0.01 & 6.17 & -0.36 & -0.13 \\
\hline \multirow[t]{10}{*}{ Other states } & 2002 & - & -0.01 & - & 0.00 & - & -0.38 & - \\
\hline & 2003 & - & -0.01 & - & 0.00 & - & -0.33 & - \\
\hline & 2004 & - & -0.01 & - & 0.00 & - & -0.29 & - \\
\hline & 2005 & - & -0.01 & - & 0.00 & - & -0.22 & - \\
\hline & 2006 & - & -0.01 & - & 0.00 & - & -0.27 & - \\
\hline & 2007 & - & -0.02 & - & 0.00 & - & -0.40 & - \\
\hline & 2008 & - & -0.01 & - & 0.00 & - & -0.27 & - \\
\hline & 2009 & - & -0.01 & - & 0.00 & - & -0.25 & - \\
\hline & 2010 & - & -0.01 & - & 0.00 & - & -0.30 & - \\
\hline & 2011 & - & -0.01 & - & -0.01 & - & -0.27 & - \\
\hline
\end{tabular}

Note: HRS, hard red spring; HRW, hard red winter; SWW, soft white winter; WSU, Washington State University. 
Table 7. Consumer and Total Surplus Changes (2011 Dollars per Capita)

\begin{tabular}{|c|c|c|c|c|}
\hline \multirow[b]{2}{*}{ Year } & \multicolumn{4}{|c|}{ Change in Consumer Surplus } \\
\hline & Washington & Idaho & Oregon & United States \\
\hline 2002 & 0.003 & 0.003 & 0.003 & 0.003 \\
\hline 2003 & 0.002 & 0.002 & 0.002 & 0.002 \\
\hline 2004 & 0.002 & 0.002 & 0.002 & 0.002 \\
\hline 2005 & 0.002 & 0.002 & 0.002 & 0.002 \\
\hline 2006 & 0.002 & 0.002 & 0.002 & 0.002 \\
\hline 2007 & 0.003 & 0.003 & 0.003 & 0.003 \\
\hline 2008 & 0.002 & 0.002 & 0.002 & 0.002 \\
\hline 2009 & 0.002 & 0.002 & 0.002 & 0.002 \\
\hline 2010 & 0.002 & 0.002 & 0.002 & 0.002 \\
\hline \multirow[t]{2}{*}{2011} & 0.002 & 0.002 & 0.002 & 0.002 \\
\hline & \multicolumn{4}{|c|}{ Change in Total Surplus } \\
\hline Year & Washington & Idaho & Oregon & United States \\
\hline 2002 & 0.853 & 0.631 & 0.079 & 0.022 \\
\hline 2003 & 0.889 & 0.579 & 0.063 & 0.021 \\
\hline 2004 & 0.817 & 0.501 & 0.072 & 0.020 \\
\hline 2005 & 0.653 & 0.369 & 0.029 & 0.016 \\
\hline 2006 & 0.712 & 0.314 & 0.010 & 0.017 \\
\hline 2007 & 0.976 & 0.540 & 0.037 & 0.024 \\
\hline 2008 & 0.677 & 0.354 & 0.044 & 0.016 \\
\hline 2009 & 0.542 & 0.357 & 0.001 & 0.013 \\
\hline 2010 & 0.760 & 0.270 & -0.029 & 0.017 \\
\hline 2011 & 0.766 & 0.166 & -0.032 & 0.017 \\
\hline
\end{tabular}

To provide some perspective about the magnitude of these surplus changes, we divide the change in producer surplus by the number of acres to get changes in surplus in dollars per acre and the change in consumer and total surplus by population to get changes in surplus in dollars per capita. Tables 5 and 6 present surplus changes in 2011 dollars per acre, and Table 7 presents surplus changes in 2011 dollars per capita. Overall, producer surplus increases by approximately $\$ 1.57$ to $\$ 2.90$ per acre per year in Washington, illustrating the high percentage of Washington producers using varieties developed at WSU. Producer surplus increases by 18 to 73 cents per acre per year in Idaho. Producer surplus increases by 3 to 28 cents per acre per year from 2002 to 2008, with no change in 2009, and decreases by 13 cents in 2010 and 2011 in Oregon, revealing a lower proportion of producers using WSU varieties as compared with Idaho and Washington. On aggregate terms, producer surplus increases from 6 to 10 cents per acre per year in the United States, showing the balance between producers using WSU varieties and other varieties. Results by wheat class are not surprising; most of the benefits go to producers of SWW, $\$ 0.72$ to $\$ 1.24$ per acre per year, while producers of all other wheat classes gain at most 5 cents per acre per year, but closer to zero in most years. 
To gauge the impact of producer surplus per acre, we calculate the increase in producer surplus for the average wheat farm in Washington, Idaho, and Oregon. We use data on average farm size by state from the 2002 and 2007 USDA Census of Agriculture (2014). Producer surplus increased by \$895 in 2002 and $\$ 1,105$ in 2007 for the average wheat farm in Washington (426 acres in 2002 and 381 acres in 2007). Producer surplus increased by \$343 in 2002 and \$295 in 2007 for the average wheat farm in Idaho (470 acres in 2002 and 454 acres in 2007). Producer surplus increased by $\$ 120$ in 2002 and \$64 in 2007 for the average wheat farm in Oregon (427 acres in 2002 and 425 acres in 2007). These values vary by state because of the specific producer surplus estimates and average farm size and suggest that the increase in producer surplus because of the WSU wheat breeding programs is economically important.

Total surplus increases for Washington by 54 to 98 cents per capita per year; for Idaho, by 17 to 63 cents per capita per year; and for Oregon, by 1 to 8 cents per capita per year from 2002 to 2008, with no change for 2009, and decreased total surplus by 3 cents for 2010 and 2011. These results show that in Washington, Idaho, and Oregon, most of the benefits go to producers using WSU varieties because increases in total surplus are only slightly higher than increases in producer surplus. Given the large quantities of wheat produced in those states relative to the average consumption per capita, this result is no surprise. Net effects for the United States as an aggregate are increases in total surplus of 1 to 2 cents per capita per year. Overall, in the United States the gains to consumers and producers using WSU varieties are larger than the losses to producers using other varieties.

\subsection{Economic Assessment and Returns}

To formally evaluate the WSU wheat breeding programs, it is important to compare the benefits with the costs incurred to fund these programs. As mentioned earlier, funds for the WSU wheat breeding programs come from a variety of sources, including state, federal, and university sources and the Washington Wheat Commission. We have presented a detailed analysis of the changes in surplus for several regions because of the use of varieties developed by WSU. Now we compare these net benefits with the cost of research.

To incorporate the lagged effect of wheat breeding research, we assume that 10 years is the time required to develop and release a new variety (it can take 7 to 12 years from the development to the marketing and adoption of a new wheat variety). Average estimates of expenditures for WSU wheat breeding research from 1993 to 2011 range from \$0.51 million to \$2.09 million per year (Table 8). The benefits are the total surplus changes for all wheat classes (Table 2) for 2002 to 2011. We then use the 5-year average from 2007 to 2011 and assume a decrease of benefits of $10 \%$ per year until all benefits are depleted in 2020 (Nalley et al., 2008). 
Table 8. Cost and Social Welfare of WSU Wheat Breeding Programs (2011 Million Dollars)

\begin{tabular}{lcl}
\hline \hline Year & Benefits & Cost WSU Breeding Programs \\
\hline 1993 & - & $\$ 1.536$ \\
1994 & - & $\$ 1.527$ \\
1995 & - & $\$ 1.514$ \\
1996 & - & $\$ 1.499$ \\
1997 & - & $\$ 1.492$ \\
1998 & - & $\$ 1.496$ \\
1999 & - & $\$ 1.490$ \\
2000 & - & $\$ 1.467$ \\
2001 & $\$ 7.796$ & $\$ 1.452$ \\
2002 & $\$ 7.673$ & $\$ 1.342$ \\
2003 & $\$ 7.161$ & $\$ 2.018$ \\
2004 & $\$ 5.599$ & $\$ 1.781$ \\
2005 & $\$ 6.291$ & $\$ 2.092$ \\
2006 & $\$ 8.974$ & $\$ 0.729$ \\
2007 & $\$ 5.805$ & $\$ 0.802$ \\
2008 & $\$ 4.892$ & $\$ 0.718$ \\
2009 & $\$ 6.509$ & $\$ 0.843$ \\
2010 & $\$ 6.399$ & $\$ 0.509$ \\
2011 & $\$ 5.864$ & - \\
2012 & $\$ 5.213$ & - \\
2013 & $\$ 4.561$ & - \\
2014 & $\$ 3.910$ & - \\
2015 & $\$ 3.258$ & - \\
2016 & $\$ 2.606$ & - \\
2017 & $\$ 1.955$ & - \\
2018 & $\$ 1.303$ & - \\
2019 & $\$ 0.652$ & \\
2020 & $\$ 5.075$ & - \\
Average & - & - \\
\hline \hline
\end{tabular}

Note: WSU, Washington State University. Benefits are total surplus changes for all wheat classes (Table 2). Costs are average estimates of expenditures for WSU wheat breeding research.

Following Nalley et al. (2008), we calculate the BCR, the NPV, and the IRR. For a baseline scenario, we obtain a BCR of 1.75 , an NPV of $\$ 9.13$ million, and an IRR of $17.75 \%$, assuming a $10 \%$ discount rate (Table 9). For completeness, results for $5 \%, 10 \%$, and $15 \%$ discount rates and the different price elasticities of supply for the United States $(0.1,0.22$, and 0.5$)$ are presented as well. Hence, we obtain a range of values for the BCR, NPV, and IRR given the range of price elasticities of supply for the U.S. wheat and discount rates considered. Relative to the baseline, the more inelastic U.S. wheat supply and lower discount rates increase total benefits and consequently provide a higher economic impact (BCR equals 5.61, NPV equals $\$ 79.043$ million, and IRR equals $29.30 \%$ when the price elasticity of supply for U.S. wheat is 0.1 and the discount rate is $5 \%$ ). On 
Table 9. Sensitivity Analysis of Economic Impact

\begin{tabular}{|c|c|c|c|}
\hline \multicolumn{4}{|l|}{ Benefit-Cost Ratio } \\
\hline \multirow[b]{2}{*}{ Price elasticity of supply U.S. } & \multicolumn{3}{|c|}{ Discount Rate } \\
\hline & 0.05 & 0.1 & 0.15 \\
\hline$\overline{0.1}$ & 5.61 & 3.87 & 2.69 \\
\hline 0.22 & 2.54 & $1.75^{\mathrm{a}}$ & 1.22 \\
\hline 0.5 & 1.11 & 0.76 & 0.53 \\
\hline \multicolumn{4}{|c|}{ Net Present Value (2011 Million Dollars) } \\
\hline & \multicolumn{3}{|c|}{ Discount Rate } \\
\hline Price elasticity of supply U.S. & 0.05 & 0.1 & 0.15 \\
\hline$\overline{0.1}$ & 79.043 & 34.932 & 15.506 \\
\hline 0.22 & 26.370 & $9.128^{\mathrm{a}}$ & 1.986 \\
\hline 0.5 & 1.886 & -2.864 & -4.297 \\
\hline \multicolumn{4}{|l|}{ Internal Rate of Return } \\
\hline Price elasticity of supply U.S. & \multicolumn{3}{|c|}{ IRR } \\
\hline 0.1 & \multicolumn{3}{|c|}{0.2930} \\
\hline 0.22 & \multicolumn{3}{|c|}{$0.1775^{\mathrm{a}}$} \\
\hline 0.5 & \multicolumn{3}{|c|}{0.0639} \\
\hline
\end{tabular}

${ }^{a}$ Represents the baseline results.

the other extreme, a more elastic supply and a very high discount rate decrease total benefits to a level lower than the cost of research (BCR equals 0.53, NPV equals $-\$ 4.297$ million, and IRR equals $6.39 \%$ when the price elasticity of supply for U.S. wheat is 0.5 and the discount rate is $15 \%$ ). These numbers provide further evidence of the benefits for Washington, the United States, and the world of the WSU wheat breeding programs.

\subsection{Sensitivity Analysis}

Because these results are dependent on the specific elasticity values assumed, we conducted further sensitivity analysis of the price elasticities of supply and demand. Table 10 presents results for a range of values for the price elasticity of supply for the United States $(0.22,0.1,0.5$, and 1$)$ and the price elasticity of demand for the ROW $(-0.53,-0.1,-1)$, for changes in consumer, producer, and total surplus, along with the baseline results for 2011.

Changes in the value of the price elasticity of supply for the United States effect changes in consumer, producer, and total surplus for Washington, Oregon, Idaho, and the United States as a whole. An inelastic U.S. wheat supply increases the change in total surplus from approximately $\$ 6.399$ million to $\$ 14.117$ million in 2011. As the U.S. wheat supply becomes more elastic, the change in total surplus decreases to $\$ 2.807$ million in 2011. Change in total surplus decreases further to $\$ 1.401$ million in 2011 when we assume that the price elasticity of supply for the United States is equal to 1 . 
Table 10. Sensitivity Analysis of Price Elasticities of Supply and Demand for 2011

\begin{tabular}{lrrrrrr}
\hline \hline & \multicolumn{7}{c}{ Scenarios } \\
\cline { 2 - 7 } & Baseline & 1 & 2 & 3 & 4 & 5 \\
\hline Price elasticity of supply U.S. & 0.22 & 0.1 & 0.5 & 1 & 0.22 & 0.22 \\
Price elasticity of demand ROW & -0.53 & -0.53 & -0.53 & -0.53 & -0.1 & -1 \\
Producer surplus change WA & 5.213 & 12.032 & 2.132 & 0.995 & 4.481 & 5.426 \\
Producer surplus change U.S. & 4.566 & 11.936 & 1.470 & 0.499 & 2.024 & 5.290 \\
Consumer surplus change WA & 0.013 & 0.016 & 0.010 & 0.006 & 0.031 & 0.008 \\
Consumer surplus change U.S. & 0.598 & 0.711 & 0.436 & 0.294 & 1.397 & 0.369 \\
Total surplus change WA & 5.226 & 12.047 & 2.142 & 1.001 & 4.511 & 5.434 \\
Total surplus change U.S. & 5.164 & 12.647 & 1.906 & 0.794 & 3.420 & 5.658 \\
Total surplus change all & 6.399 & 14.117 & 2.807 & 1.401 & 6.311 & 6.419 \\
\hline \hline
\end{tabular}

Note: Changes in surplus are in 2011 million dollars. ROW, rest of the world.

Changes in the value of the price elasticity of demand for the ROW have a smaller effect on changes in consumer, producer, and total surplus for Washington, Oregon, Idaho, and the United States than do changes in the value of the price elasticity of supply for the United States. When the ROW wheat demand becomes inelastic, the change in total surplus decreases from $\$ 6.399$ million to $\$ 6.311$ million in 2011. As the ROW wheat demand becomes elastic, the change in total surplus increases to $\$ 6.419$ million in 2011 . The pattern for Washington and the United States is the same.

\section{Conclusions}

This article presents welfare effects of the WSU wheat breeding programs using a multiproduct, multiregion, multivariety model including spillover effects to Idaho and Oregon. Given the specific characteristics of the different wheat classes and regions, we believe that it is important to introduce these differences into the model to obtain more accurate results because information is lost by aggregating all wheat classes and regions into one. Finally, we use an improved empirical measure of breeder contributions to yield for WSU varieties, netting out as much as possible management and other effects that overinflate measures of welfare and return on investment.

Overall, consumers in all regions and producers using WSU-developed varieties have increased surplus from yield increases in wheat because of WSU wheat breeding programs, attributable to the combination of lower prices and higher yields of WSU varieties over parts of the study period. However, producers using non-WSU varieties and producers of other wheat classes have in general decreased surplus because of lower prices and constant yields. It is important to note that this model is partial equilibrium, and thus, we are holding constant all 
other potential yield increases by technology or other wheat breeding programs to concentrate on the effect of WSU wheat breeding programs. Changes in total surplus are positive for all regions. ${ }^{11}$ However, the surplus changes in Idaho and Oregon are much smaller relative to the increases in Washington, and the net effects for the United States are positive.

We have analyzed the important question of whether funds allocated to the WSU wheat breeding programs had a reasonable return. We compare the expenditures in the WSU wheat breeding programs with the benefits calculated with our model, and we find that for each dollar spent there is $\$ 1.75$ in benefits, considering a 10-year lag to release a new variety. The NPV of the program from 1993 to 2020 is $\$ 9.13$ million (2011 dollars), and the IRR is $17.75 \%$. Our results are important for WSU and policy makers in general because they provide justification for the current funds allocated to the wheat breeding programs.

\section{References}

Akino, M., and Y. Hayami. "Efficiency and Equity in Public Research: Rice Breeding in Japan's Economic Development." American Journal of Agricultural Economics 57(February 1975):1-10.

Alston, J.M., G.W. Norton, and P.G. Pardey. Science under Scarcity: Principles and Practice for Agricultural Research Evaluation and Priority Setting. Ithaca, NY: Cornell University Press, 1995.

Alston, J.M., and P.G. Pardey. "Attribution and Other Problems in Assessing the Returns to Agricultural R\&D.” Agricultural Economics 25(2001):141-52.

Ayer, H.W., and G.E. Schuh. "Social Rates of Return and Other Aspects of Agricultural Research: The Case of Cotton Research in Sao Paulo, Brazil.” American Journal of Agricultural Economics 54(November 1972):557-69.

Barkley, A.P. Kansas Wheat Breeding: An Economic Analysis. Manhattan, KS: Kansas State University Agricultural Experiment Station and Cooperative Extension Service, Report of Progress 793, 1997.

Berwald, D., C.A. Carter, and G.P. Gruère. "Passing Up New Technology: An Illustration from the Global Wheat Market.” Working paper, University of California, Davis, April 2005.

Blakeslee, L., and R. Sargent. Economic Impacts of Public Research and Extension Related to Wheat Production in Washington. Pullman, WA: Agricultural Research Center, Washington State University, Research Bulletin XB 0929, 1982.

Blakeslee, L., E.E. Weeks, P.J. Bourque, W.B. Beyers, and W.R. Seyfried. Wheat in the Washington Economy: An Input-Output Study. Pullman, WA: Washington State University College of Agriculture Research Center, Bulletin 775, April 1973.

Brennan, J.P. “An Analysis of the Economic Potential of Some Innovations in a Wheat Breeding Programme.” Australian Journal of Agricultural Economics 33(1989):48-55.

—. "Measuring the Contribution of New Varieties to Increasing Wheat Yields." Review of Marketing and Agricultural Economics 52(1984):175-95.

11 Note, however, that we hold all other yield improvements constant in this study, underestimating the total surplus changes for Oregon and Idaho. Our analysis is only to measure welfare effects of WSU wheat breeding programs. 
Brennan, J.P., D.L. Godyn, and B.G. Johnston. “An Economic Framework for Evaluating New Wheat Varieties.” Review of Marketing and Agricultural Economics 57(1989):7592.

Byerlee, D., and G. Traxler. "National and International Wheat Improvement Research in the Post-Green Revolution Period: Evolution and Impact." American Journal of Agricultural Economics 77(May 1995):268-78.

Crespi, J.M., S. Grunewald, A.P. Barkley, J.A. Fox, and T.L. Marsh. Potential Economic Impacts from the Introduction of Genetically Modified Wheat on the Export Demand for US Wheat. Manhattan, KS: Department of Agricultural Economics, Kansas State University. Report prepared for the Kansas Wheat Commission, May 2005.

DeVuyst, E.A., W.W. Koo, C.S. DeVuyst, and R.D. Taylor. Modeling International Trade Impacts of Genetically Modified Wheat Introductions. Fargo, ND: Center for Agricultural Policy and Trade Studies, Department of Agribusiness and Applied Economics, Agricultural Experiment Station, North Dakota State University, Agribusiness and Applied Economics Report No. 463, October 2001.

Edwards, G.W., and J.W. Freebairn. "The Gains from Research into Tradable Commodities." American Journal of Agricultural Economics 66(1984):41-49.

Feyerherm, A.M., G.M. Paulsen, and J.L. Sebaugh. "Contribution of Genetic Improvement to Recent Wheat Yield Increases in the USA.” Agronomy Journal 76(1984):985-90.

GAMS Development Corporation. General Algebraic Modeling System (GAMS) Release 23.7.3. Washington, DC: GAMS Development Corporation, 2011.

Griliches, Z. "Research Costs and Social Returns: Hybrid Corn and Related Innovations." Journal of Political Economy 66(1958):419-31.

Heisey, P.W., M.A. Lantican, and H.J. Dubin. Impacts of International Wheat Breeding Research in Developing Countries, 1966-97. Mexico, D.F., Mexico: Centro Internacional de Mejoramiento de Maíz y Trigo (CIMMYT), 2002.

Jones, S. Breeding Wheat for Sustainable, Perennial and Organic Systems. Pullman, WA: Washington State University, Department of Crop and Soil Sciences. Internet site: http://css.wsu.edu/research/crop_genetics/Jones.htm (Accessed September 2006).

Koo, W.W., and R.D. Taylor. 2006 Outlook of the U.S. and World Wheat Industries, 20052015. Fargo, ND: Center for Agricultural Policy and Trade Studies, North Dakota State University, Agribusiness and Applied Economics Report No. 586, July 2006.

Marsh, T.L. "Economic Substitution for US Wheat Food Use by Class." Australian Journal of Agricultural and Resource Economics 49(2005):283-301.

Michalski, J.T. "Wheat Varieties, Technology, Climate \& Yield: An Analysis Using WSU's Wheat Variety Test Data and Interpolated Weather Records.” Ph.D. dissertation, Washington State University, Pullman, 2012.

Morris, C. Personal Communication. Western Wheat Quality Laboratory, U.S. Department of Agriculture, April 2007.

Mulik, K., and W.W. Koo. Substitution between U.S. and Canadian Wheat by Class. Fargo, ND: Center for Agricultural Policy and Trade Studies, North Dakota State University, Agribusiness and Applied Economics Report No. 587, August 2006.

Nalley, L.L., A.P. Barkley, and F. Chumley. "The Impact of the Kansas Wheat Breeding Program on Wheat Yields, 1911-2006." Journal of Agricultural and Applied Economics 40(2008):913-25.

Nalley, L.L., A.P. Barkley, J.M. Crespi, and K.D Sayre. "The Global Impact of the CIMMYT Wheat Breeding Program." Journal of International Agricultural Trade and Development 5(2008):11-29. 
Nalley, L.L., A.P. Barkley, and A.M. Featherstone. "The Genetic and Economic Impact of the CIMMYT Wheat Breeding Program on Local Producers in the Yaqui Valley, Sonora Mexico." Agricultural Economics 41(2010):453-62.

Pardey, P.G., J.M. Alston, C. Chan-Kang, E.M. Magalhaes, and S.A. Vosti. Assessing and Attributing the Benefits from Varietal Improvement Research in Brazil. Washington, DC: International Food Policy Research Institute (IFPRI), IFPRI Research Report No. 136, 2004.

- "International and Institutional R\&D Spillovers: Attribution of Benefits among Sources for Brazil's New Crop Varieties." American Journal of Agricultural Economics 88(2006):104-23.

Schultz, T.W. The Economic Organization of Agriculture. New York: McGraw-Hill, 1953.

StataCorp. Stata Statistical Software: Release 13. College Station, TX: StataCorp LP, 2013.

U.S. Census Bureau. Internet site: http://www.census.gov (Accessed March 2014).

U.S. Department of Agriculture-Census of Agriculture. Internet site: http://www.agcensus. usda.gov/ (Accessed November 2014).

U.S. Department of Agriculture-Economic Research Service (ERS). Internet site: http://www.ers.usda.gov/data/wheat/ (Accessed March 2014).

U.S. Department of Agriculture-National Agricultural Statistics Service (NASS). Internet site: http://www.nass.usda.gov/Data_and_Statistics/Quick_Stats/ (Accessed March 2014).

U.S. Department of Agriculture-National Agricultural Statistics Service (NASS) Idaho. Internet site: http://www.nass.usda.gov/Statistics_by_State/Idaho/Publications/Wheat_and_ Barley_Variety/index.asp (Accessed March 2014).

U.S. Department of Agriculture-National Agricultural Statistics Service (NASS) Oregon. Internet site: http://www.nass.usda.gov/Statistics_by_State/Oregon/Publications/ Field_Crop_Report/index.asp (Accessed March 2014).

U.S. Department of Agriculture-National Agricultural Statistics Service (NASS) Washington. Internet site: http://www.nass.usda.gov/Statistics_by_State/Washington/ Publications/Small_Grains/index.asp (Accessed March 2014).

U.S. Department of Labor-Bureau of Labor Statistics (BLS). Internet site: http://data.bls.gov/ (Accessed March 2014).

Voon, T.J., and G.W. Edwards. "Research Payoff from Quality Improvement: The Case of Protein in Australian Wheat." American Journal of Agricultural Economics 74(1992):564-72.

Washington Grain Commission. Washington Wheat Facts 2013-2014. Internet site: http://www.wawg.org/core/files/wawg/uploads/files/2013WFWeb.pdf (Accessed December 2014).

Zentner, R.P., and W.L. Peterson. "An Economic Evaluation of Public Wheat Research and Extension Expenditure in Canada." Canadian Journal of Agricultural Economics 32(July 1984):327-53. 


\section{Appendix}

Table A1. Number of Acres Planted by Region, Wheat Class, and Origin

\begin{tabular}{|c|c|c|c|c|c|c|c|c|}
\hline \multirow[b]{2}{*}{ Region } & \multirow[b]{2}{*}{ Year } & \multicolumn{2}{|c|}{ HRW } & \multicolumn{2}{|c|}{ HRS } & \multicolumn{2}{|c|}{ SWW } & \multirow[b]{2}{*}{ All } \\
\hline & & WSU & Other & WSU & Other & WSU & Other & \\
\hline \multirow[t]{10}{*}{ Washington } & 2002 & 87,500 & 57,000 & 49,200 & 110,300 & $1,268,234$ & 437,266 & $2,450,000$ \\
\hline & 2003 & 72,100 & 84,900 & 55,400 & 131,100 & $1,290,584$ & 390,916 & $2,400,000$ \\
\hline & 2004 & 86,300 & 47,200 & 65,300 & 135,700 & $1,203,017$ & 456,483 & $2,330,000$ \\
\hline & 2005 & 75,700 & 36,100 & 41,300 & 123,800 & $1,197,201$ & 537,799 & $2,280,000$ \\
\hline & 2006 & 111,400 & 90,600 & 63,200 & 212,200 & 999,517 & 647,483 & $2,280,000$ \\
\hline & 2007 & 198,500 & 211,100 & 44,800 & 188,700 & 804,634 & 596,766 & $2,170,000$ \\
\hline & 2008 & 137,200 & 110,400 & 50,100 & 198,400 & 814,700 & 686,900 & $2,290,000$ \\
\hline & 2009 & 113,600 & 99,100 & 72,800 & 219,700 & 780,317 & 706,483 & $2,290,000$ \\
\hline & 2010 & 91,400 & 130,300 & 66,900 & 210,300 & 806,166 & 719,334 & $2,330,000$ \\
\hline & 2011 & 91,200 & 122,000 & 72,300 & 234,450 & 711,917 & 843,783 & $2,380,000$ \\
\hline \multirow[t]{10}{*}{ Idaho } & 2002 & 0 & 148,000 & 0 & 276,000 & 217,000 & 359,000 & $1,150,000$ \\
\hline & 2003 & 0 & 201,000 & 0 & 295,000 & 202,600 & 347,400 & $1,190,000$ \\
\hline & 2004 & 0 & 165,000 & 4,200 & 282,800 & 171,600 & 374,400 & $1,250,000$ \\
\hline & 2005 & 0 & 175,000 & 4,700 & 199,300 & 161,750 & 423,250 & $1,260,000$ \\
\hline & 2006 & 0 & 195,000 & 10,200 & 294,800 & 128,000 & 423,000 & $1,255,000$ \\
\hline & 2007 & 0 & 280,000 & 24,600 & 225,400 & 115,550 & 380,450 & $1,235,000$ \\
\hline & 2008 & 0 & 260,000 & 21,100 & 248,900 & 98,000 & 509,000 & $1,400,000$ \\
\hline & 2009 & 0 & 230,000 & 19,150 & 263,350 & 115,900 & 460,100 & $1,310,000$ \\
\hline & 2010 & 0 & 200,000 & 17,200 & 277,800 & 77,900 & 467,100 & $1,400,000$ \\
\hline & 2011 & 0 & 174,000 & 8,700 & 275,300 & 61,250 & 579,750 & $1,471,000$ \\
\hline \multirow[t]{10}{*}{ Oregon } & 2002 & 0 & 4,200 & 800 & 27,000 & 180,733 & 615,067 & 945,000 \\
\hline & 2003 & 0 & 8,200 & 0 & 30,200 & 162,882 & 798,918 & $1,115,000$ \\
\hline & 2004 & 3,700 & 900 & 2,000 & 32,600 & 144,533 & 720,867 & 970,000 \\
\hline & 2005 & 5,400 & 4,000 & 1,800 & 37,500 & 102,700 & 717,700 & 940,000 \\
\hline & 2006 & 4,900 & 15,500 & 1,200 & 51,800 & 67,516 & 671,984 & 870,000 \\
\hline & 2007 & 9,400 & 33,800 & 1,100 & 48,200 & 70,217 & 655,583 & 855,000 \\
\hline & 2008 & 4,300 & 20,600 & 1,100 & 65,900 & 74,749 & 678,751 & 960,000 \\
\hline & 2009 & 1,600 & 22,400 & 1,000 & 43,000 & 47,900 & 688,101 & 890,000 \\
\hline & 2010 & 0 & 36,000 & 1,000 & 61,000 & 30,083 & 753,917 & 960,000 \\
\hline & 2011 & 0 & 34,000 & 500 & 60,500 & 23,167 & 772,833 & 990,000 \\
\hline
\end{tabular}

Note: HRW, hard red winter; HRS, hard red spring; SWW, soft white winter; WSU, Washington State University. 
Table A2. Own- and Cross-Price Elasticities of Demand (Marsh, 2005)

\begin{tabular}{lrrrrr}
\hline \hline & HRW & \multicolumn{1}{l}{ HRS } & \multicolumn{1}{l}{ SRW } & \multicolumn{1}{c}{ SWW } & \multicolumn{1}{c}{ DUR } \\
\hline HRW & -0.864 & 1.522 & -0.023 & 0.366 & 0.306 \\
HRS & 0.949 & -1.712 & -0.017 & -0.373 & -0.234 \\
SRW & -0.009 & -0.011 & -0.028 & 0.024 & 0.071 \\
SWW & 0.066 & -0.108 & 0.011 & -0.036 & -0.045 \\
DUR & 0.067 & -0.082 & 0.04 & -0.054 & -0.118 \\
\hline \hline
\end{tabular}

Note: DUR, durum wheat; HRS, hard red spring; HRW, hard red winter; SRW, soft red winter; SWW, soft white winter.

Table A3. Quantity Produced by Class (Million Bushels)

\begin{tabular}{lrlllr}
\hline \hline Year & \multicolumn{1}{c}{ HRW } & HRS & SWW & SRW & \multicolumn{1}{c}{ DUR } \\
\hline 2002 & 620.33 & 351.44 & 233.18 & 320.97 & 79.96 \\
2003 & $1,071.16$ & 499.67 & 297.02 & 379.93 & 96.64 \\
2004 & 856.55 & 525.47 & 304.58 & 380.31 & 89.89 \\
2005 & 930.02 & 466.59 & 297.27 & 308.35 & 101.11 \\
2006 & 681.92 & 432.34 & 251.15 & 389.54 & 53.48 \\
2007 & 955.56 & 450.07 & 221.21 & 352.03 & 72.22 \\
2008 & $1,034.69$ & 512.14 & 254.93 & 613.58 & 83.83 \\
2009 & 919.94 & 547.93 & 237.16 & 403.98 & 109.04 \\
2010 & $1,018.34$ & 569.98 & 275.10 & 237.43 & 106.08 \\
2011 & 780.09 & 397.69 & 313.55 & 457.54 & 50.48 \\
\hline \hline
\end{tabular}

Note: DUR, durum wheat; HRS, hard red spring; HRW, hard red winter; SRW, soft red winter; SWW, soft white winter. 
Table A4. Quantity Produced by Region (Million Bushels)

\begin{tabular}{|c|c|c|c|c|c|c|c|}
\hline \multirow[b]{2}{*}{ Region } & \multirow[b]{2}{*}{ Year } & \multicolumn{2}{|c|}{ HRW } & \multicolumn{2}{|c|}{ HRS } & \multicolumn{2}{|c|}{ SWW } \\
\hline & & WSU & Other & WSU & Other & WSU & Other \\
\hline \multirow[t]{10}{*}{ Washington } & 2002 & 5.08 & 3.31 & 2.12 & 4.74 & 73.56 & 25.36 \\
\hline & 2003 & 4.69 & 5.52 & 2.27 & 5.38 & 83.89 & 25.41 \\
\hline & 2004 & 5.78 & 3.16 & 3.27 & 6.79 & 80.60 & 30.58 \\
\hline & 2005 & 5.07 & 2.42 & 1.82 & 5.45 & 80.21 & 36.03 \\
\hline & 2006 & 7.24 & 5.89 & 3.16 & 10.61 & 64.97 & 42.09 \\
\hline & 2007 & 12.31 & 13.09 & 2.06 & 8.68 & 49.89 & 37.00 \\
\hline & 2008 & 7.68 & 6.18 & 2.10 & 8.33 & 45.62 & 38.47 \\
\hline & 2009 & 6.70 & 5.85 & 3.28 & 9.89 & 46.04 & 41.68 \\
\hline & 2010 & 6.31 & 8.99 & 3.48 & 10.94 & 55.63 & 49.63 \\
\hline & 2011 & 6.84 & 9.15 & 4.48 & 14.54 & 53.39 & 63.28 \\
\hline \multirow[t]{10}{*}{ Idaho } & 2002 & 0.00 & 11.40 & 0.00 & 17.94 & 16.71 & 27.64 \\
\hline & 2003 & 0.00 & 16.08 & 0.00 & 19.47 & 16.21 & 27.79 \\
\hline & 2004 & 0.00 & 14.85 & 0.33 & 22.34 & 15.44 & 33.70 \\
\hline & 2005 & 0.00 & 15.93 & 0.34 & 14.35 & 14.72 & 38.52 \\
\hline & 2006 & 0.00 & 15.02 & 0.74 & 21.52 & 9.86 & 32.57 \\
\hline & 2007 & 0.00 & 20.44 & 1.67 & 15.33 & 8.44 & 27.77 \\
\hline & 2008 & 0.00 & 19.50 & 1.52 & 17.92 & 7.35 & 38.18 \\
\hline & 2009 & 0.00 & 18.63 & 1.47 & 20.28 & 9.39 & 37.27 \\
\hline & 2010 & 0.00 & 16.40 & 1.34 & 21.67 & 6.39 & 38.30 \\
\hline & 2011 & 0.00 & 14.27 & 0.73 & 23.13 & 5.02 & 47.54 \\
\hline \multirow[t]{10}{*}{ Oregon } & 2002 & 0.00 & 0.18 & 0.03 & 0.97 & 7.59 & 25.83 \\
\hline & 2003 & 0.00 & 0.42 & 0.00 & 1.21 & 8.31 & 40.74 \\
\hline & 2004 & 0.23 & 0.05 & 0.10 & 1.56 & 8.82 & 43.97 \\
\hline & 2005 & 0.33 & 0.24 & 0.09 & 1.95 & 6.26 & 43.78 \\
\hline & 2006 & 0.25 & 0.81 & 0.06 & 2.59 & 3.51 & 34.94 \\
\hline & 2007 & 0.50 & 1.79 & 0.05 & 2.31 & 3.72 & 34.75 \\
\hline & 2008 & 0.25 & 1.19 & 0.05 & 2.97 & 4.34 & 39.37 \\
\hline & 2009 & 0.09 & 1.25 & 0.05 & 2.32 & 2.68 & 38.53 \\
\hline & 2010 & 0.00 & 2.41 & 0.07 & 4.15 & 2.02 & 50.51 \\
\hline & 2011 & 0.00 & 2.62 & 0.04 & 4.24 & 1.78 & 59.51 \\
\hline
\end{tabular}

Note: HRS, hard red spring; HRW, hard red winter; SWW, soft white winter; WSU, Washington State University. 
Table A5. Quantity Consumed, Exports, and Price

\begin{tabular}{|c|c|c|c|c|c|}
\hline \multirow{3}{*}{$\frac{\text { Year }}{2002}$} & HRW & HRS & SRW & SWW & DUR \\
\hline & \multicolumn{5}{|c|}{ Quantity Consumed (Million Bushels) } \\
\hline & 377.13 & 215.00 & 165.00 & 80.00 & 81.49 \\
\hline 2003 & 378.08 & 223.00 & 153.00 & 85.00 & 72.85 \\
\hline 2004 & 382.05 & 228.00 & 155.00 & 75.00 & 69.50 \\
\hline 005 & 370.33 & 227.00 & 155.00 & 85.00 & 79.79 \\
\hline 2006 & 365.80 & 236.00 & 165.00 & 85.00 & 86.12 \\
\hline 2007 & 397.21 & 233.00 & 150.00 & 85.00 & 82.66 \\
\hline 2008 & 384.55 & 224.16 & 155.00 & 85.00 & 78.07 \\
\hline 2009 & 361.01 & 238.51 & 156.00 & 83.00 & 80.41 \\
\hline 2010 & 359.18 & 247.40 & 150.00 & 85.00 & 84.06 \\
\hline 2011 & 403.60 & 222.79 & 155.00 & 85.00 & 75.00 \\
\hline Year & \multicolumn{5}{|c|}{ Exports (Million Bushels) } \\
\hline 2002 & 307.71 & 258.08 & 104.67 & 147.25 & 32.50 \\
\hline 2003 & 510.44 & 271.85 & 137.67 & 192.08 & 46.30 \\
\hline 2004 & 389.39 & 315.30 & 122.44 & 207.77 & 31.01 \\
\hline 2005 & 427.71 & 280.15 & 76.10 & 173.51 & 45.31 \\
\hline 2006 & 280.29 & 247.98 & 145.29 & 195.37 & 39.55 \\
\hline 2007 & 536.12 & 304.17 & 207.94 & 169.38 & 45.00 \\
\hline 2008 & 446.90 & .94 & 19 & 13 & 23.83 \\
\hline 2009 & 369.65 & 213.66 & 109.12 & 143.01 & 43.86 \\
\hline 2010 & 616.89 & 339.74 & 109.17 & 181.96 & 43.69 \\
\hline 2011 & 397.32 & 242.53 & 165.26 & 218.92 & 27.06 \\
\hline Year & \multicolumn{5}{|c|}{ Price (2011 Dollars/Bushel) } \\
\hline 2002 & 5.15 & 5.87 & 4.72 & 5.64 & 6.21 \\
\hline 2003 & 4.70 & 5.28 & 4.61 & 5.15 & 5.78 \\
\hline 2004 & 4.51 & 4.81 & 4.40 & 4.82 & 5.28 \\
\hline 2005 & 4.32 & 4.72 & 4.07 & 4.00 & 4.42 \\
\hline 2006 & 5.53 & 5.47 & 4.12 & 5.05 & 5.41 \\
\hline 2007 & 7.16 & 8.34 & 6.06 & 8.42 & 11.55 \\
\hline 2008 & 7.31 & 7.83 & 6.13 & 6.37 & 9.82 \\
\hline 2009 & 5.63 & 6.11 & 5.06 & 5.25 & 6.36 \\
\hline 2010 & 7.06 & 7.12 & 5.62 & 6.40 & 6.51 \\
\hline 2011 & 6.92 & 8.38 & 6.78 & 6.42 & 9.68 \\
\hline
\end{tabular}

Note: DUR, durum wheat; HRS, hard red spring; HRW, hard red winter; SRW, soft red winter; SWW, soft white winter. 